the sky, which had been generally overcast, was rapidly breaking up into masses of cumulus clouds separated by wide spaces of blue. About a dozen waterspouts were seen in all, the ship passing right through one of them and thus enabling me to estimate its diameter by direct comparison with the known beam of the Servia.

The swirls of spray rose from the sea in a cup-like shape, and revolving rapidly in a direction opposite to that of the hands of a watch. It was only after such a swirl had become well defined that the lower surface of the cumulus cloud above it began to descend as if to meet it, spinnin $x$ at the same time. Indeed, so inconspicuous was this feature of the phenomenon that many of the passengers, intent on watching the spray-cups sparkling brightly in the sunshine, failed to notice it at all. In no case did the cloud swirl nearly meet the sea swirl, nor did the double-
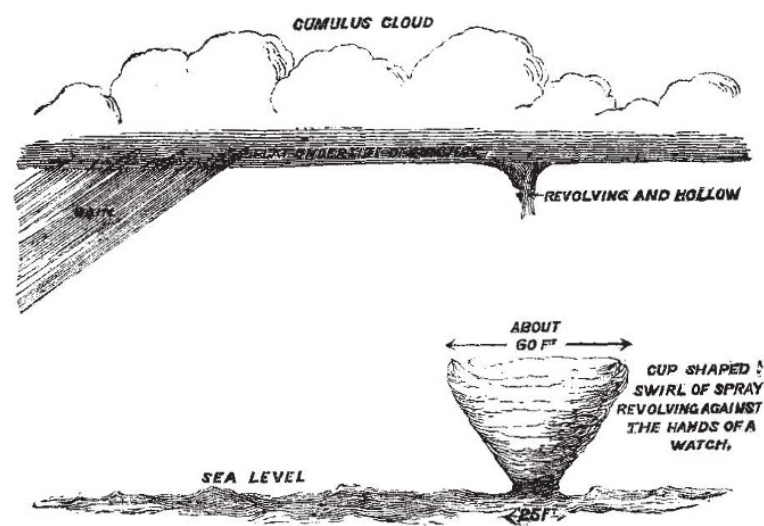

funneled stem of whirling mist, so generally shown in books, appear. Some spray fell heavily on deck from the swirl through which the Servia passed, but the wind, which struck us at one moment on this, at the other on that, side of the face was not brisk enough to carry off any one's hat. The sight was remarkably beautiful whether closely or distantly viewed. In the one case the spray-cup seemed made of rustling jewels which sparkled in the bright sunshine; in the other, the sea horizon appeared as if here and there set with boiling and steaming caldrons, whose rope-like handles hung from the dark undersides of white billowy cloud:

Hartford, Mass., U.S.A., May 22

\section{Meteors of June 3}

The large meteor seen by Mr. Hall and others (NATURE, vol. xxviii. pp. 126, I 50) was also observed here by Mr. Paul Mathews and myself. We estimated the length of its path while visible as $120^{\circ}$ with the middle part due east, the direction of its motion as parallel to the horizon, elevation as $20^{\circ}$, and length of tail as $25^{\circ}$; its apparent brilliance I put at six times, Mr. Mathews at twice, the greatest brilliance of Venus, and the pieces into which it broke up (about six in number) as equal to the brightest planets. The time I should have put at 10.50 , but did not note it (Mr. Mathews 10.40 to 10.45). The colour was golden. This was moreover in a very clear and brilliant sky, as about 1o we had observed that the light in the east was so intense that it cast quite a dark shadow as we passed through a somewhat shady part of the road.

Ripon

W. W. TAYLOR

IN the correspondence on the large meteor seen on June 3 I have not seen any notice of another curious meteor seen later on the same night. A flash of light is the sky drew attention to it, and when first seen it was moving in nearly a straight line from IO2 Herculis to a Aquilæ. In five seconds it travelled slightly more than half the distance to the latter star, and then disappeared without any outburst. It was about a lunar diameter in length, and between $3^{\prime}$ and $4^{\prime}$ wide at the widest part, a point distant one-third of its entire length from the head. In fact it was not at all unlike a comet with a bushy tail tapering off to a point. The colour was a pale ye!low.

P. F. D.

\section{Intelligence in Animals}

SOME years since, when calling on the late Hon. Marmaduke Maxwell of Terregles, our conversation happened to turn on the subject of intelligence and instinct of animals. Mr. Maxwell said if I would walk down to the stables with him he would show me a curious instance. On reaching the stable he pointed out an empty stall in which five well grown young rats were running about-a board had been fixed at the end of the stall to prevent the rats getting out. Some time before the cat had a litter of five kittens, three were taken from her and drowned; the following morning it was found she bad brought in three young rat;, which she suckled with the two kittens that had been left ; a few days afterwards the two kittens were destroyed, and the next morning it was found the cat had brought in two more young rats. While we were looking at this strange foster family the cat came into the stable, jumped over the board and lay down, when the rats at once ran under her and commenced sucking. What makes the matter the more singular is, the coachman told me the cat was a particularly good ratter, and was kept in the stable for the purpose of keeping down rats.

Cargen, Dumfries

P. DUDGEON

\section{AMERICAN ETHNOLOGY}

U NDER the able management of Major J. W. Powell the Bureau of Ethnology, recently attached to the Smithsonian Institution, has already done much useful work in the wide field of American anthropology. This first annual report, however, of its proceedings for the year ending July, I880, appears to be somewhat behind time for, although bearing on the title-page the date of $188 \mathrm{r}$, it was not issued to the public till the beginning of the present year. But the delay is doubtless due to the large amount of preliminary work required to be got through in organising the department, and future reports may be expected to appear more punctually. The title, "Annual Report," is itself somewhat misleading, the actual report of the director really occupying no more than thirty-three introductory pages, and consisting mainly of a digest of the rich materials filling a large quarto volume of over 600 pages. Hence this is, strictly speaking, a first volume of the Proceedings or Transactions of the Bureau, and as such gives fair promise of a long and useful career in an anthropological domain which may be regarded as practically unlimited.

From the director's introductory remarks we gather that, after the fusion in 1879 of the various geological and geographical surveys in the general "United States Geological Surve)," the Bureau of Ethnology was created and attached to the Smithsonian Institution for the purpose of continuing the anthropological work which had hitherto been prosecuted in a somewhat desultory way by those Surveys. The management of this newlyorganised department was intrusted to Major Powell, who, as former Director of the Survey of the Rocky Mountain Region, had already shown special aptitude for ethnological investigation. The direct object of the Bureau, we are told, is to systematise anthropological research in America, and this it is proposed to effect both by the prosecution of research through the direct employment of students and specialists, and by the general encouragement and guidance of original observers cooperating throughout the continent." "It has been the effort of the Bureau to prosecute work in the various branches of North American anthropology on a syste matic plan, so that every important field should be cultivated, limited only by the amount appropriated by Congress" (xiv.).

How closely this wide programme has been so far adhered to is evident from the varied contents of this

1 "First Annual Report of the Bureau of Ethnology, Smithsonian Institution, I879-80." By J. W. Powell, Director. (Washington Government Printing Office, 188I). 